\title{
Impact of foliar nickel application on urease activity, antioxidant metabolism and control of powdery mildew (Microsphaera diffusa) in soybean plants
}

\author{
J. P. Q. Barcelos ${ }^{a}$, H. P. G. Reis ${ }^{a}$, C. V. Godoy ${ }^{b}$, P. L. Gratão ${ }^{c}$, E. Furlani Junior ${ }^{a}$, \\ F. F. Putti ${ }^{d}$, M. Campos ${ }^{d}$ and A. R. Reis ${ }^{\text {ad* }}$ \\ a São Paulo State University - UNESP, Ilha Solteira, SP, 15385-000; ' ${ }^{2}$ mbrapa Soybean, Rodovia Carlos João Strass - Distrito de Warta, \\ Londrina, 86001-970, PR; ' São Paulo State University - UNESP, Jaboticabal, 79560-000, SP; and dSão Paulo State University - UNESP, \\ Tupã, 17602-496, SP, Brazil
}

Nickel $(\mathrm{Ni})$ is a cofactor for urease, an enzyme that breaks down urea into ammonia and carbon dioxide. This study aimed to evaluate the physiological impact of $\mathrm{Ni}$ on urea, antioxidant metabolism and powdery mildew severity in soybean plants. Seven levels of $\mathrm{Ni}\left(0,10,20,40,60,80\right.$ and $\left.100 \mathrm{~g} \mathrm{ha}^{-1}\right)$ alone or combined with the fungicides fluxapyroxad and pyraclostrobin were applied to soybean plants. The total $\mathrm{Ni}$ concentration ranged from 3.8 to $38.0 \mathrm{mg} \mathrm{kg}^{-1}$ in leaves and 3.0 to $18.0 \mathrm{mg} \mathrm{kg}^{-1}$ in seeds. A strong correlation was observed between Ni concentration in the leaves and seeds, indicating translocation of $\mathrm{Ni}$ from leaves to seeds. Application of $\mathrm{Ni}$ above $60 \mathrm{~g} \mathrm{ha}^{-1}$ increased lipid peroxidation in the leaf tissues, indicative of oxidative stress. Application of $40 \mathrm{~g} \mathrm{ha}^{-1} \mathrm{Ni}$ combined with $300 \mathrm{~mL} \mathrm{ha}^{-1}$ of fungicide reduced powdery mildew severity by up to $99 \%$. Superoxide dismutase, catalase, peroxidase and urease enzyme activity were greatest under these conditions. Urea concentration decreased in response to $\mathrm{Ni}$ application. Urease activity in soybean leaves showed a negative correlation with powdery mildew severity. The leaf Ni concentration showed a positive correlation with the urease and a negative correlation with powdery mildew severity. The results of this study suggest that urease is a key enzyme regulated by $\mathrm{Ni}$ and has a role in host defence against powdery mildew by stimulating antioxidant metabolism in soybean plants.

Keywords: antioxidative metabolism, fungicides, nickel, soybean, urea, urease

\section{Introduction}

As a result of improved disease management and plant breeding programmes, soybean (Glycine max) has increased in production over the last few decades. Fertilizer application and effective pest and disease control are the main management practices adopted to ensure high soybean yield (Godoy et al., 2016).

Disease occurrence is one of the limiting factors for higher soybean yields (Godoy et al., 2016). Powdery mildew, caused by the fungus Microsphaera diffusa, develops on the leaf surface, forming a thin layer of mycelium and reducing the photosynthetic active area by up to $50 \%$. This leads to leaf drying and premature fall in severe cases, thereby causing yield losses of $10-50 \%$ (McTaggart et al., 2012).

The most efficient method of controlling powdery mildew is the use of resistant cultivars. However, some resistant cultivars become susceptible when sown in seasons most favourable to the occurrence of powdery

*E-mail: andrereis@tupa.unesp.br, andrekun@gmail.com

Published online 21 May 2018 mildew (Godoy et al., 2016), and require fungicide application. The use of a fungicide mixture with at least two active ingredients with different actions, such as a strobilurin and a carboxamide fungicide, is recommended to avoid fungal resistance to chemicals. Both active ingredients block fungal mitochondrial respiration, but they act on distinct sites. In addition, these molecules are known to exert a positive physiological effect on plant antioxidant metabolism, fighting both biotic and abiotic stress (Godoy et al., 2016).

An economically viable alternative for controlling powdery mildew is foliar fertilization with micronutrients. When applied at low concentrations, $\mathrm{Ni}$ can reduce fungal diseases when used alone or in combination with fungicides. The nutritional status of the plant determines susceptibility to the disease. The essential role of $\mathrm{Ni}$ in plants was demonstrated by Dixon et al. (1975), who found that this metal is a structural component of the metalloenzyme urease (urea amidohydrolase), which has two $\mathrm{Ni}$ ions in its active centre (Ciurli, 2001). This enzyme catalyses the hydrolysis of urea into ammonia and carbon dioxide (Dixon et al., 1975). The importance of $\mathrm{Ni}$ has been shown in several plant species, as observed by Eskew et al. (1983) and Brown et al. (1987), who found low urease activity in soybean, bean and barley due to $\mathrm{Ni}$ deficiency, 
resulting in an accumulation of urea in the leaf tissue. Urease occurs in two isoenzymatic forms in soybean plants, one of high expression called embryo-specific urease, synthesized in the seed, and the other called ubiquitous urease, which is synthesized in the other plant tissues and plays an important role in nitrogen metabolism (Polacco et al., 2013; Fabiano et al., 2015).

In addition to the nutritional effects of $\mathrm{Ni}$ on nitrogen metabolism, this micronutrient can directly affect pathogenic microorganisms, as reported for bacteria and fungi (Wood \& Reilly, 2007; Wiebke-Strohm et al., 2012). Foliar spraying with $\mathrm{Ni}$ at low concentrations also increases tolerance to biotic and abiotic stress in plants because this micronutrient stimulates antioxidant metabolism, increasing the activity of enzymes of the ascorbate-glutathione cycle, such as catalase (CAT), peroxidase (POD) and superoxide dismutase (SOD), which protect plant cells against reactive oxygen species (ROS) (Noctor \& Foyer, 2016).

Foliar application of $\mathrm{Ni}$ alone or combined with chemical control with fungicides may be a viable alternative for the management of powdery mildew in soybean. This study aimed to evaluate the physiological and biochemical effect of $\mathrm{Ni}$ alone or combined with chemical control with fungicides on powdery mildew control and its relation with nutritional status, antioxidative stress, and nitrogen metabolism in soybean plants.

\section{Materials and methods}

\section{Experimental site}

The study was conducted from March to June 2015 at the Teaching and Research Farm of the Engineering School of Ilha Solteira, São Paulo State University (FEIS/UNESP) in Selvíria,

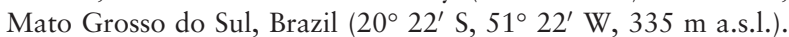
The experimental site is part of the Cerrado biome, and it has been cultivated for more than 25 years and has been under a no-tillage system for the last 10 years. The mean annual rainfall is $1232 \mathrm{~mm}$, and the mean annual temperature is $24.5^{\circ} \mathrm{C}$. During the experiment, the mean daily temperature ranged from 27.2 to $15.3^{\circ} \mathrm{C}$, the mean daily rainfall was $3.0 \mathrm{~mm}$, and the mean relative humidity was $86 \%$ (Fig. 1 ).

The soil of the site was classified as a typical dystrophic red latosol (DRL) that is very clayey and corresponds to the oxisol order. The chemical characteristics of the soil were $29 \mathrm{mg} \mathrm{dm}^{-3}$ phosphorus (resin), $21 \mathrm{~g} \mathrm{dm}^{-3}$ organic matter, calcium chloride $\left(\mathrm{CaCl}_{2}\right) \mathrm{pH} 5.3,3.5 \mathrm{mmol}_{\mathrm{c}} \mathrm{dm}^{-3}$ potassium, $38 \mathrm{mmol}_{\mathrm{c}} \mathrm{dm}^{-3}$ calcium, $22 \mathrm{mmol}_{\mathrm{c}} \mathrm{dm}^{-3}$ magnesium, $8 \mathrm{mmol}_{\mathrm{c}} \mathrm{dm}^{-3} \mathrm{H}^{+}+\mathrm{Al}, 0$ $\mathrm{mmol}_{\mathrm{c}} \mathrm{dm}^{-3}$ aluminium, $0.1 \mathrm{mg} \mathrm{dm}{ }^{-3}$ nickel, $92.5 \mathrm{mmol}_{\mathrm{c}} \mathrm{dm}^{-3}$ cation exchange capacity, and $69 \%$ base saturation $(\mathrm{V} \%)$.

\section{Experimental design}

The study was conducted using a randomized block experimental design with a $7 \times 2$ factorial scheme, including seven doses of $\mathrm{Ni}\left(0,10,20,40,60,80\right.$ and $\left.100 \mathrm{~g} \mathrm{ha}^{-1}\right)$, using nickel sulphate as the source, alone or combined with $300 \mathrm{~mL} \mathrm{ha}^{-1}$ of the fungicide Orkestra SC, applied during phenological stage R1 (beginning bloom), with four replicates, totalling 56 plots. The fungicide Orkestra SC was chosen because it is registered with the Brazilian Ministry of Agriculture and Livestock for the control of soybean diseases, including powdery mildew. In addition, this fungicide is of interest to this study because the physiological actions of the active ingredients (fluxapyroxad and pyraclostrobin) on the plant are known (Godoy et al., 2016).

\section{Experimental set-up and procedures}

The experiment was conducted under a no-tillage system. Soil acidity was not corrected because the base saturation was adequate for the soybean requirements. The area was desiccated 20 days before sowing with Roundup Original (glyphosate, $4 \mathrm{~L} \mathrm{ha}^{-1}$ ), Aurora $400 \mathrm{EC}$ (carfentrazone-ethyl, $200 \mathrm{~mL} \mathrm{ha}^{-1}$ ), and $0.5 \%$ mineral oil.

The soybean cultivar TMG 7062 IPRO (semideterminate growth, white flower, short cycle, susceptible to powdery mildew, INOX technology, and Intacta RR2 PRO), previously treated with Standak Top ( $2 \mathrm{~mL} \mathrm{~kg}^{-1}$ seed), was seeded at a density of approximately 267000 plants per hectare. The experimental plots consisted of four $6-\mathrm{m}$ rows spaced $0.45 \mathrm{~m}$ apart, and the useful area included the two central rows, excluding $0.5 \mathrm{~m}$ at the ends.

The seeds were inoculated simultaneously with $3 \mathrm{~mL} \mathrm{ha}^{-1}$ of the liquid commercial product and the nitrogen-fixing bacterium Bradyrhizobium japonicum (strain SEMIA 6462, product registration number SP 00581-10030-1, $2 \times 10^{9}$ colony-forming units $\mathrm{g}^{-1}$, BIOMAX). For fertilization with NPK, $350 \mathrm{~kg} \mathrm{ha}^{-1}$ of 4-30-10 fertilizer was applied.

The soybean seeds were sown on 5 March 2015, and the seedlings emerged 7 days after seeding. The late sowings or winter interim-harvest and cultivation are periods more favourable to powdery mildew occurrence because the fungus requires temperatures of approximately $18-24^{\circ} \mathrm{C}$ and low relative humidity for development (Godoy et al., 2016).

When necessary, irrigation was performed by a centre-pivot sprinkler system, with a mean water depth of $14 \mathrm{~mm}$ and $72 \mathrm{~h}$ irrigation time. During the plant development cycle, phytosanitary control was performed with Roundup Original (glyphosate, $4 \mathrm{~L} \mathrm{ha}^{-1}$ ), Premio (chlorantraniliprole, $50 \mathrm{~mL} \mathrm{ha}^{-1}$ ), Belt (flubendiamide, $60 \mathrm{~mL} \mathrm{ha}^{-1}$ ) and Connect (imidacloprid + betacyfluthrin, $0.8 \mathrm{~L} \mathrm{ha}^{-1}$ ).

The use of a soybean variety susceptible to powdery mildew, along with a site favourable to the natural appearance of the disease and in the ideal season and climatic conditions for its development, was sufficient for the natural occurrence of powdery mildew, making inoculation unnecessary.

\section{Physiological and biochemical analysis}

\section{Evaluation of growth and yield}

The number of pods on the plants, excluding the empty pods, was evaluated at the R8 (full maturity) stage. The evaluation was performed in three plants from each plot. Yield was evaluated at the same stage, by harvesting the plants from the plots. Moisture was standardized at $13 \%$.

\section{Evaluation of disease severity}

The severity of disease was evaluated using a scoring system based on percentage of the leaf area with visible disease symptoms, using a diagrammatic scale (Godoy et al., 2016).

\section{Scanning electron microscopy}

At the R2 (full bloom) stage, 12 days after treatment application, leaf samples from the upper third of one plant of each plot 


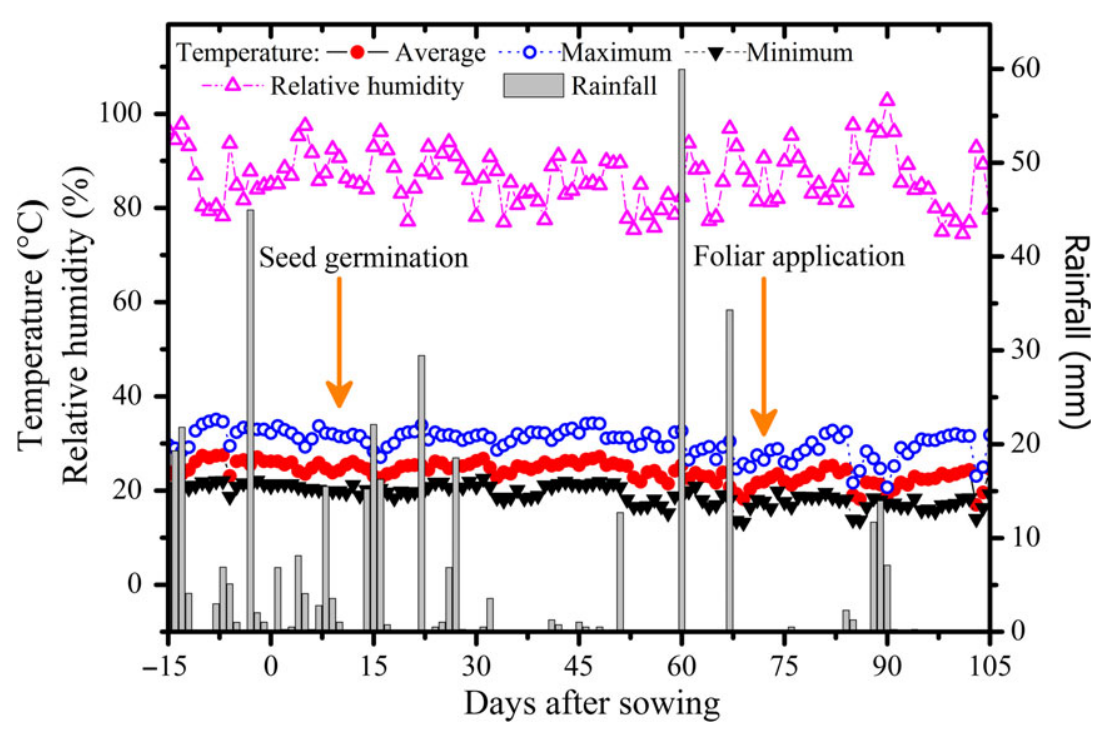

Figure 1 Rainfall $(\mathrm{mm})$; relative air humidity (\%); and minimum, mean, and maximum temperature $\left({ }^{\circ} \mathrm{C}\right)$ during the experiment in the municipality of Selvíria, Mato Grosso do Sul, Brazil. [Colour figure can be viewed at wileyonlinelibrary.com]

were collected. Square leaf samples of approximately $0.5 \mathrm{~mm}^{2}$ were subjected to a gold bath for approximately $3 \mathrm{~min}$ in a Quorum Q150T sputter coater. Next, the samples were placed under a Zeiss EVO LS-15 scanning electron microscope, where images were obtained using secondary electron detectors (to observe leaf relief and topography) and backscattered electron detectors (to observe the contrast in the leaves due to the presence of chemical elements of different atomic numbers).

\section{Nutritional analysis}

At the R2 stage, 12 days after the treatment application, the first newly expanded trefoil was collected from 20 plants in each plot. The material was dried and used to quantify the foliar macro- and micronutrient concentration. The seeds collected at the R8 stage were also analysed.

The nitrogen concentration was determined by the semimicro-Kjeldahl method after sulphur digestion and nitricperchloric acid digestion were used to quantify the other nutrients (Santos et al., 2017). The determination was made using atomic absorption spectroscopy, except for phosphorus and sulphur, whose concentrations were determined using spectrophotometry as described by Reis et al. (2015).

\section{Enzymatic analysis}

Collection of material. The first fully expanded trefoil of the plants was collected in liquid nitrogen 10 days after the treatments for determination of the enzymatic activities. This material was macerated in liquid nitrogen and stored at $-80{ }^{\circ} \mathrm{C}$ until analysis. Samples were removed from the leaves to quantify the concentration of urea, shikimic acid, hydrogen peroxide, lipid peroxidase, soluble protein, superoxide dismutase, catalase and peroxidase.

Urease activity. In vivo urease activity was determined as a function of $\mathrm{N}-\mathrm{NH}_{4}$ production, according to the method of McCullough (1967). The extract was obtained according to the method described by Hogan et al. (1983). After collection, $0.2 \mathrm{~g}$ of fresh leaf mass was added to $8 \mathrm{~mL}$ of sodium phosphate buffer with urea $\mathrm{pH} 7.4$ and kept for $3 \mathrm{~h}$ in a $30{ }^{\circ} \mathrm{C}$ water bath with stirring for extraction. Then, $2.5 \mathrm{~mL}$ of reagent $\mathrm{I}$, comprising phenol $(0.1 \mathrm{M})$ and sodium nitroprusside $(170 \mu \mathrm{M})$, was added to a $0.5 \mathrm{~mL}$ aliquot of the extract, followed by stirring, and then the addition of $2.5 \mathrm{~mL}$ of reagent II, comprising sodium hydroxide $(0.125 \mathrm{M})$, disodium phosphate $(0.15 \mathrm{M})$ and sodium hypochlorite $\left(3 \% \mathrm{Cl}_{2}\right)$. The mixture was incubated again in a $37{ }^{\circ} \mathrm{C}$ water bath for $35 \mathrm{~min}$. $\mathrm{N}-\mathrm{NH}_{4}$ production was determined with a spectrophotometer at $625 \mathrm{~nm}$, and the results are expressed in $\mu \mathrm{mol} \mathrm{N-NH}$ per g FW (fresh weight) $\mathrm{h}^{-1}$.

Urea concentration. The urea concentration was determined as described by Kojima et al. (2007). One millilitre of formic acid $(10 \mathrm{~mm})$ was added to $0.5 \mathrm{~g}$ of plant material, followed by vortexing and centrifugation of the sample at $10000 \mathrm{~g}$ at $4{ }^{\circ} \mathrm{C}$ for $15 \mathrm{~min}$. An acid reagent was prepared that contained ferric chloride hexahydrate and orthophosphoric acid, which, when mixed with sulphuric acid, formed the mixed acid reagent. Then, two colourimetric reagents, one containing thiosemicarbazide and the other containing diacetyl monoxime, were combined. The final reagent, called colour-developing reagent, was prepared only on the day of the test, by mixing ultrapure water, the mixed acid reagent and the mixed colourimetric reagent at the ratio of $1: 1: 1$. For urea determination, $1 \mathrm{~mL}$ of the prepared reagent was added to $100 \mu \mathrm{L}$ of sample. The samples were incubated at $99^{\circ} \mathrm{C}$ for $15 \mathrm{~min}$, under stirring at $750 \mathrm{rpm}$, and then cooled for $5 \mathrm{~min}$ on ice and kept in the dark. The determination was performed in a spectrophotometer at $540 \mathrm{~nm}$, and the results are expressed in $\mu \mathrm{mol}$ urea per $\mathrm{g}$ FW.

Shikimic acid concentration. For determination of shikimic acid concentration, the method described by Singh \& Shaner (1998) was used. A total of $750 \mu \mathrm{L}$ of hydrochloric acid $(0.25 \mathrm{M})$ was added to $250 \mathrm{mg}$ plant material at a ratio of $1: 3$. The material was homogenized by vortexing and was then centrifuged at $10606 \mathrm{~g}$ for $15 \mathrm{~min}$ at $4{ }^{\circ} \mathrm{C}$. Twenty microlitres of the sample was mixed with $0.5 \mathrm{~mL}$ of periodic acid solution $(1 \%)$. The solution was allowed to stand for $3 \mathrm{~h}$. Next, $0.5 \mathrm{~mL}$ 
of sodium hydroxide $(1 \mathrm{M})$ and $0.3 \mathrm{~mL}$ of glycine $(0.1 \mathrm{M})$ were added. The readings were performed immediately in a spectrophotometer at $380 \mathrm{~nm}$, and the results are expressed in $\mu \mathrm{mol}$ of shikimic acid per $\mathrm{g}$ FW.

Hydrogen peroxide concentration. The hydrogen peroxide $\left(\mathrm{H}_{2} \mathrm{O}_{2}\right)$ concentration was determined by reaction of the plant sample with potassium iodide (KI), according to Alexieva et al. (2001). One hundred milligrams of frozen plant material was mixed with $1 \mathrm{~mL}$ of $0.1 \%$ trichloroacetic acid (TCA) in an Eppendorf tube, homogenized by vortexing, and then centrifuged at $7780 \mathrm{~g}$ for $15 \mathrm{~min}$ at $4{ }^{\circ} \mathrm{C}$. Then, $200 \mu \mathrm{L}$ of potassium phosphate buffer $\mathrm{pH} 7.5(100 \mathrm{mM})$ and $800 \mu \mathrm{L}$ of $\mathrm{KI}$ solution $(1 \mathrm{M})$ were added to $200 \mu \mathrm{L}$ of the supernatant. The samples were kept on ice for $1 \mathrm{~h}$. The samples were then allowed to return to room temperature, and the absorbance was read at $390 \mathrm{~nm}$. The hydrogen peroxide concentration in the leaf tissue was calculated based on a standard curve, and the results are expressed in nmol per $\mathrm{g}$ FW.

Lipid peroxidation. Lipid peroxidation was determined by the production of metabolites reactive to 2-thiobarbituric acid (TBA), mainly malondialdehyde (MDA), according to Heath \& Packer (1968). The extraction was performed by homogenizing $200 \mathrm{mg}$ of plant material in $2 \mathrm{~mL}$ of $0.1 \%$ TCA $(\mathrm{w} / \mathrm{v})+20 \%$ polyvinylpolypyrrolidone (PVPP). The homogenate was centrifuged at $7780 \mathrm{~g}$ for $5 \mathrm{~min}$ at $4{ }^{\circ} \mathrm{C}$. Then, $1 \mathrm{~mL}$ of a solution containing $20 \%$ TCA $+0.5 \%$ TBA was added to $250 \mu \mathrm{L}$ of supernatant. The samples were kept in a dry bath at $95{ }^{\circ} \mathrm{C}$ for $30 \mathrm{~min}$ and then transferred to ice, where they remained for another $10 \mathrm{~min}$. Next, the material was centrifuged again at $7780 \mathrm{~g}$ for $10 \mathrm{~min}$. Samples were read at two wavelengths: 532 and $600 \mathrm{~nm}$. The results are expressed in nmol MDA per $\mathrm{g}$ FW.

Enzyme extraction and activity. The frozen plant material was macerated in a mortar with liquid nitrogen. Subsequently, the extract obtained from approximately $1 \mathrm{~g}$ of processed plant material was transferred to a $15 \mathrm{~mL}$ Falcon tube, where $5 \mathrm{~mL}$ of $100 \mathrm{~mm}$ potassium phosphate buffer $(\mathrm{pH}$ 6.8, containing $1 \mathrm{~mm}$ ethylenediaminetetraacetic acid (EDTA), $3 \mathrm{~mm}$ dithiothreitol (DTT), and $4 \%(\mathrm{w} / \mathrm{v})$ PVPP) was added, according to the method described by Santos et al. (2017). The homogenate was centrifuged at $7780 \mathrm{~g}$ for $30 \mathrm{~min}$, and the supernatant was stored at $-80{ }^{\circ} \mathrm{C}$ for further determination of the SOD, CAT and POD activities. The protein concentration was determined following the method of Bradford (1976), with bovine serum albumin being used as a standard.

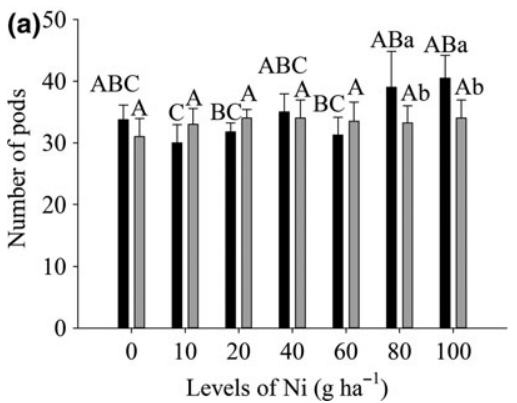

SOD activity was determined according to Giannopolitis \& Ries (1977). The reaction was performed in a reaction chamber (box), under a $15 \mathrm{~W}$ fluorescent lamp at $25^{\circ} \mathrm{C}$. Fifty microlitres of the sample was added to $5 \mathrm{~mL}$ of the following solution: sodium phosphate buffer $\mathrm{pH} 7.8$ (50 mM), methionine (13 mM), nitroblue tetrazolium (NBT, $75 \mathrm{~mm})$, EDTA $(0.1 \mathrm{~mm})$ and riboflavin $(2 \mu \mathrm{M})$. The samples were placed in the box while covered and unexposed to any exterior light, and kept under box illumination for $15 \mathrm{~min}$. In parallel, the same solution was kept in the dark in test tubes capped with aluminium foil, constituting the blank for each sample. Subsequently, the samples were homogenized by vortexing. The determination was carried out in a spectrophotometer at $560 \mathrm{~nm}$, and the results are expressed in $\mathrm{U}$ SOD per mg protein.

CAT activity was determined by monitoring the $\mathrm{H}_{2} \mathrm{O}_{2}$ degradation according to the method described by Reis et al. (2015). One millilitre of potassium phosphate buffer $\mathrm{pH} 7.5$ (100 mM) and $2.5 \mu \mathrm{L}$ of $\mathrm{H}_{2} \mathrm{O}_{2}(30 \%)$ were added to $25 \mu \mathrm{L}$ of the protein extract, and the samples were immediately vortexed. The determination of the $\mathrm{H}_{2} \mathrm{O}_{2}$ decomposition was performed at $2 \mathrm{~min}$ intervals at $25{ }^{\circ} \mathrm{C}$ in a spectrophotometer at $240 \mathrm{~nm}$, and the results are expressed in nmol per mg protein.

POD activity was determined according to the method described by Reis et al. (2014), with small changes. Phosphate buffer solution $\mathrm{pH} 6.7, \mathrm{H}_{2} \mathrm{O}_{2}(30 \%)$, amino-antipyrine and phenol were added to $150 \mu \mathrm{L}$ of protein extract, with subsequent incubation in a water bath at $30^{\circ} \mathrm{C}$ for $5 \mathrm{~min}$. Next, $2 \mathrm{~mL}$ of ethanol was added, and the samples were vortexed. The determination was performed in a spectrophotometer at $505 \mathrm{~nm}$, and the results are expressed in $\mu \mathrm{mol}$ per min per mg protein.

\section{Statistical analysis}

The normality of all data was tested using the Anderson-Darling test, and the homoscedasticity was tested using the equality of variances test (or Levene's test). The data were subjected to analysis of variance at a significance level of 0.05 probability by the $F$ test. When significant, the means were subjected to the Tukey test at the 0.05 probability level using the statistical programs Minitab and SigMAPLOT.

\section{Results}

The number of pods of soybean increased in response to $\mathrm{Ni}$ application (Fig. 2a), and the soybean yield increased in response to fungicide application (Fig. 2b). However,

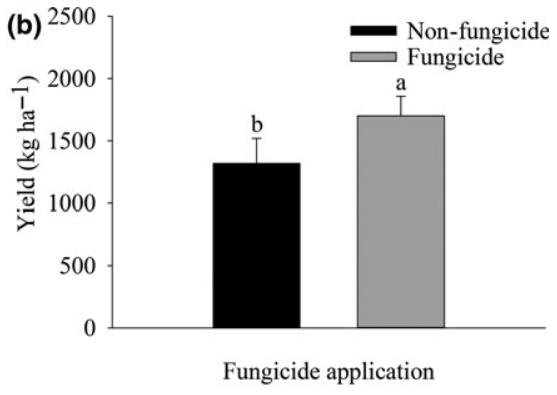

Figure 2 Number of pods and soybean yield in response to Ni application alone (black bars) or combined with fungicide (fluxapyroxad + pyraclostrobin; grey bars). Means followed by the same uppercase and lowercase letters are not significantly different according to the $t$-test $(P \leq 0.05)$, following a horizontal comparison of bars from the different $\mathrm{Ni}$ doses and presence or absence of fungicide, respectively. The error bars represent the standard error of the mean $(n=4)$. 

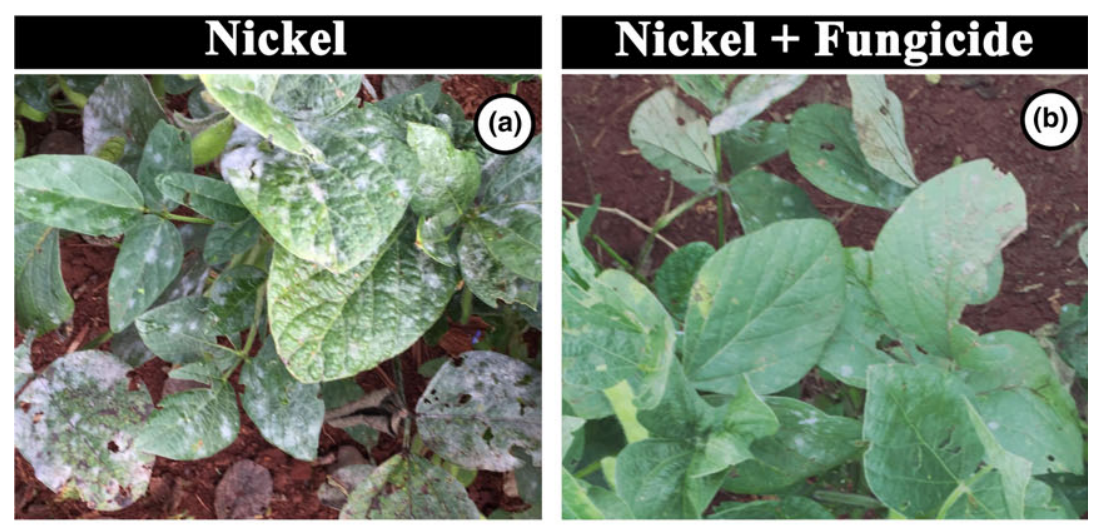

Figure 3 Soybean powdery mildew severity in response to the application of $\mathrm{Ni}$ doses alone or combined with fungicide. (a) Control (no application of $\mathrm{Ni}$ or fungicide); (b) application of $300 \mathrm{~mL} \mathrm{ha}^{-1}$ fungicide (fluxapyroxad + pyraclostrobin) only; (c) application of $10 \mathrm{~g} \mathrm{ha}^{-1}$ of $\mathrm{Ni}$; (d) application of $10 \mathrm{~g} \mathrm{ha}^{-1} \mathrm{Ni}+$ $300 \mathrm{~mL} \mathrm{ha}^{-1}$ fungicide; (e) application of $60 \mathrm{~g} \mathrm{ha}^{-1} \mathrm{Ni}$; (f) application of $60 \mathrm{~g} \mathrm{ha}^{-1}$ $\mathrm{Ni}+300 \mathrm{~mL} \mathrm{ha}^{-1}$ fungicide; (g) application of $100 \mathrm{~g} \mathrm{ha}^{-1} \mathrm{Ni}$; (h) application of $100 \mathrm{~g} \mathrm{ha}^{-1}$ $\mathrm{Ni}+300 \mathrm{~mL} \mathrm{ha}^{-1}$ fungicide. [Colour figure can be viewed at wileyonlinelibrary.com]
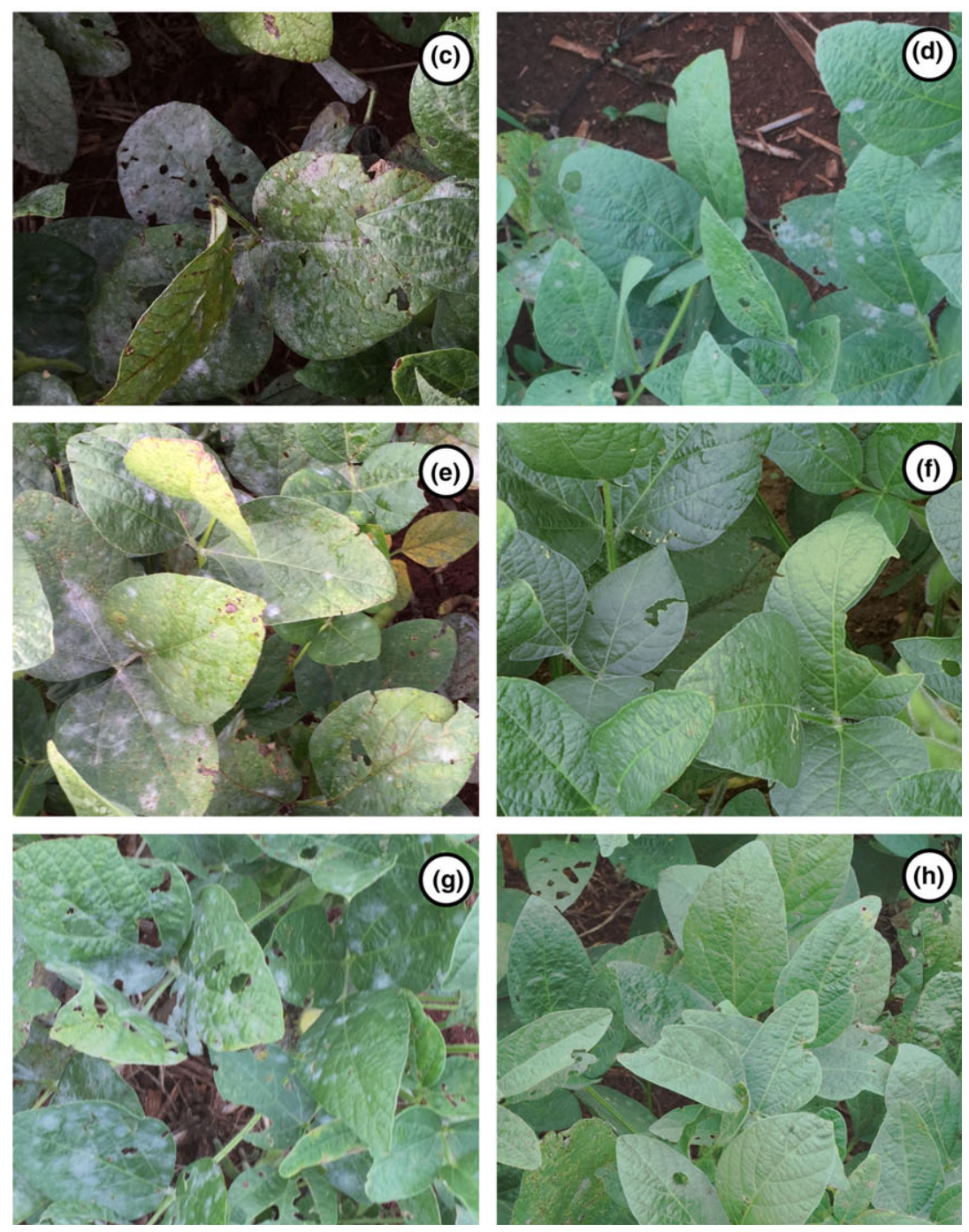

soybean yield did not increase in response to $\mathrm{Ni}$ foliar application.

Figures 3 and 4 clearly show the antifungal effect of the foliar application of $\mathrm{Ni}$, with or without fungicide, with a reduction in powdery mildew severity. Treatments with $60 \mathrm{~g} \mathrm{ha}^{-1}$ of $\mathrm{Ni}$ combined with $300 \mathrm{~mL} \mathrm{ha}^{-1}$ fungicide decreased fungal severity by
$99 \%$, leaving the leaves intense green (Fig. 3). The electron micrographic images (Fig. 4) show the effect of $\mathrm{Ni}$ on the fungal reproductive structures (conidia) and on the hyphae. In the control treatment the conidia and hyphae were visible (Fig. 4a). With the application of $\mathrm{Ni}$, these structures were either damaged (Fig. 4c) or did not develop. Notably, even the higher 
$\mathrm{Ni}$ doses did not cause Ni toxicity in the leaf or ultrastructural alterations.

$\mathrm{Ni}$ applications rates from $20 \mathrm{~g} \mathrm{Ni} \mathrm{ha}^{-1}$ led to lower disease severity (Fig. 5). Control of the powdery mildew was more effective when nickel was combined with the fungicide. Applications starting at $40 \mathrm{~g} \mathrm{ha}^{-1}$ of $\mathrm{Ni}$ combined with $300 \mathrm{~mL} \mathrm{ha}^{-1}$ of fungicide significantly decreased the disease severity in soybean. When applied alone, $\mathrm{Ni}$ was more effective in controlling the disease at applications of 80 and $100 \mathrm{~g} \mathrm{ha}^{-1}$ (Fig. 5).

Foliar $\mathrm{Ni}$ application combined with the fungicide altered the leaf nitrogen concentration in the soybean plants (Fig. 6a). Among the other nutrients, manganese and iron concentration in the soybean seeds varied according to the $\mathrm{Ni}$ dose, alone or combined with the fungicide (Fig. 6b,c). Foliar Ni concentration increased in response to $\mathrm{Ni}$ application rates (Fig. 6d). The manganese concentration did not differ significantly until the dose of $80 \mathrm{~g} \mathrm{ha}^{-1}$. Similar to the foliar tissue, the dose of $20 \mathrm{~g} \mathrm{ha}^{-1}$ led to slightly higher manganese concentration in seeds (Fig. 7a,b).

The application of $\mathrm{Ni}$ at doses between 10 and $40 \mathrm{~g} \mathrm{ha}^{-1}$, alone or combined with fungicide, increased the urease activity (Fig. 8a). The urea concentration in soybean leaves decreased (Fig. 8b) with foliar $\mathrm{Ni}$ application.

Nickel acts on the shikimic acid pathway that is responsible for biosynthesis of aromatic amino acids such as phenylalanine, tryptophan and tyrosine (Kutman et al., 2013). The shikimic acid concentration remained constant with foliar $\mathrm{Ni}$ application, except for the $40 \mathrm{~g} \mathrm{ha}^{-1}$ application rate, which showed a peak in

Figure 4 Electron micrograph of conidium and hypha of Microsphaera diffusa in soybean leaves in response to the application of $\mathrm{Ni}$ doses alone or combined with fungicide. (a) Control (no application of $\mathrm{Ni}$ or fungicide); (b) application of $300 \mathrm{~mL} \mathrm{ha}^{-1}$ fungicide (fluxapyroxad + pyraclostrobin) only; (c) application of $10 \mathrm{~g} \mathrm{ha}^{-1}$ $\mathrm{Ni}$; (d) application of $10 \mathrm{~g} \mathrm{ha}^{-1} \mathrm{Ni}+300 \mathrm{~mL}$ $\mathrm{ha}^{-1}$ fungicide; (e) application of $60 \mathrm{~g} \mathrm{ha}^{-1} \mathrm{Ni}$; (f) application of $60 \mathrm{~g} \mathrm{ha}^{-1} \mathrm{Ni}+300 \mathrm{~mL} \mathrm{ha}^{-1}$ fungicide; (g) application of $100 \mathrm{~g} \mathrm{ha}^{-1} \mathrm{Ni}$; (h) application of $100 \mathrm{~g} \mathrm{ha}^{-1} \mathrm{Ni}+300 \mathrm{~mL} \mathrm{ha}^{-1}$ fungicide. Arrows indicate details of the hypha and conidium of $M$. diffusa. [Colour figure can be viewed at wileyonlinelibrary.com]
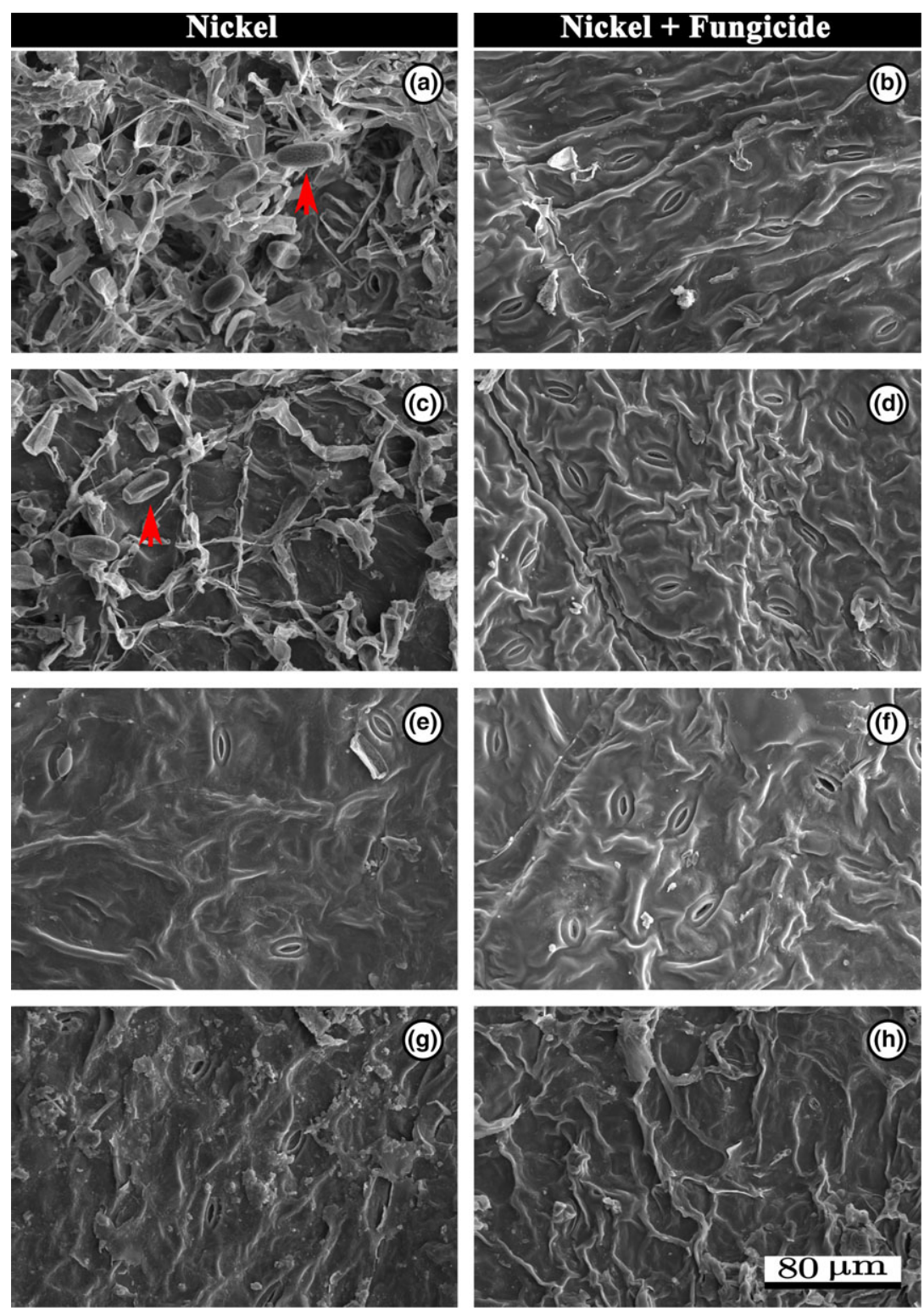


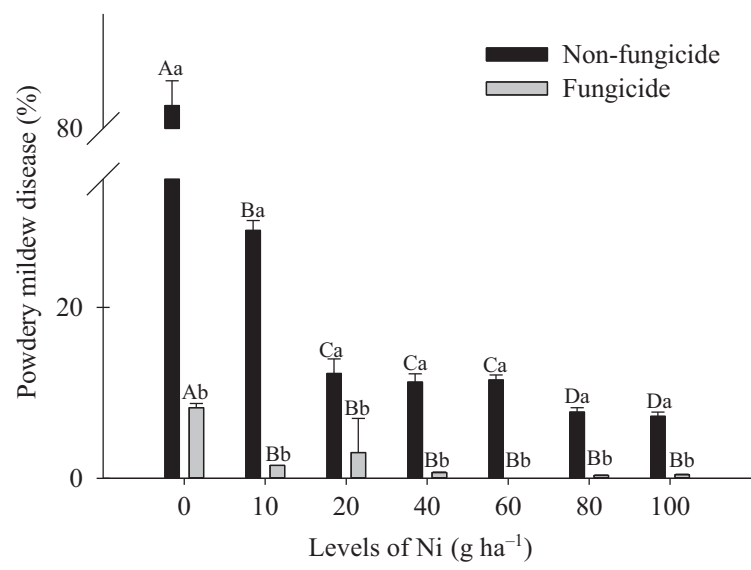

Figure 5 Percentage of powdery mildew on soybean trefoils as a function of the application of Ni doses alone (black bars) or combined with fungicide (fluxapyroxad + pyraclostrobin; grey bars). Means followed by the same lowercase letter comparing the fungicide application and by the same uppercase letter comparing the Ni doses do not differ significantly $(P \leq 0.05)$ according to the Tukey test. Error bars indicate the standard deviation of the mean of four replicates $(n=4)$.
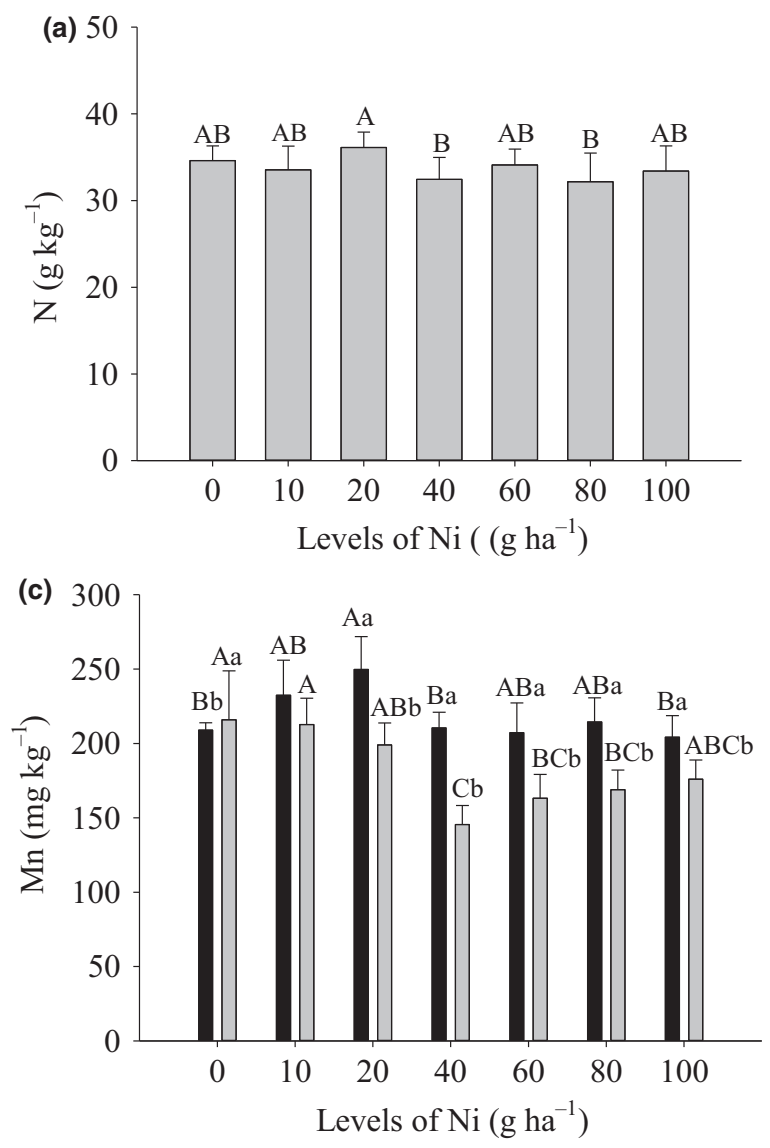

shikimic acid concentration (Fig. 9a). However, for the treatments with fungicide, a reduction in the shikimic acid concentration was observed at the higher doses.

SOD is a key enzyme that acts in the first line of defence against ROS, being responsible for the conversion of superoxide $\left(\mathrm{O}_{2}{ }^{\cdot-}\right)$ into the less toxic forms $\mathrm{H}_{2} \mathrm{O}_{2}$ and $\mathrm{O}_{2}$ (Thakur \& Sohal, 2013). In the present study, the application of $\mathrm{Ni}$ up to the dose of $60 \mathrm{~g} \mathrm{ha}^{-1}$ promoted a linear increase in SOD activity (Fig. 9b), and for the same $\mathrm{Ni}$ doses combined with the fungicide, the SOD activity was significantly higher compared to the application of $\mathrm{Ni}$ alone. The CAT activity also increased in response to foliar $\mathrm{Ni}$ application up to $60 \mathrm{~g} \mathrm{ha}^{-1}$ relative to the control. The POD activity (Fig. 9d) increased up to $40 \mathrm{~g} \mathrm{ha}^{-1}$ of $\mathrm{Ni}$.

The $\mathrm{H}_{2} \mathrm{O}_{2}$ concentration was lower in the treatments that combined $\mathrm{Ni}$ and fungicide application when compared to treatments in which $\mathrm{Ni}$ was applied alone. Foliar application of $\mathrm{Ni}$ up to $60 \mathrm{~g} \mathrm{ha}^{-1}$ increased the $\mathrm{H}_{2} \mathrm{O}_{2}$ concentration (Fig. 9e). By contrast, the lipid peroxidation rate increased in response to $\mathrm{Ni}$ doses when applied in combination with fungicide (Fig. 9f). In the absence of fungicide, no change was observed in the lipid
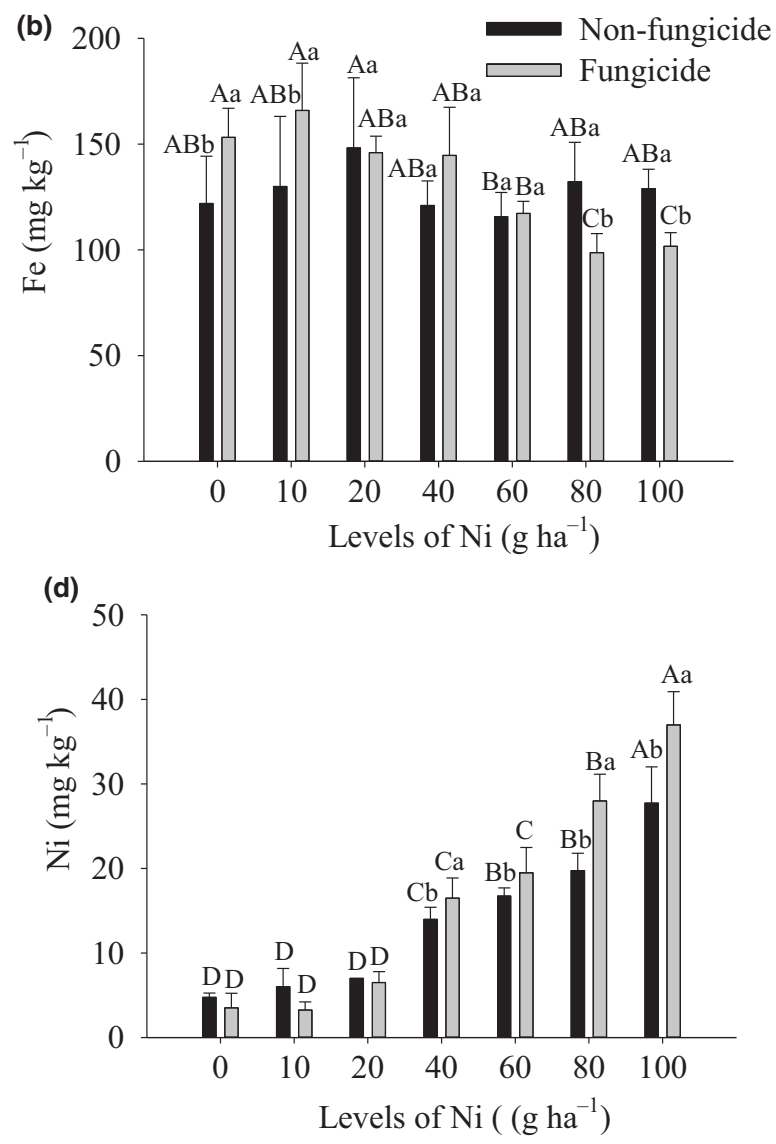

Figure 6 Nitrogen and micronutrient leaf contents in soybean in response to Ni application alone (black bars) or combined with fungicide (fluxapyroxad + pyraclostrobin; grey bars). (a) Nitrogen, (b) iron, (c) manganese, (d) nickel. Means followed by the same lowercase letter comparing the fungicide application and by the same uppercase letter comparing the Ni doses do not differ significantly $(P \leq 0.05)$ according to the Tukey test. The error bars represent the standard error of the mean $(n=4)$. 

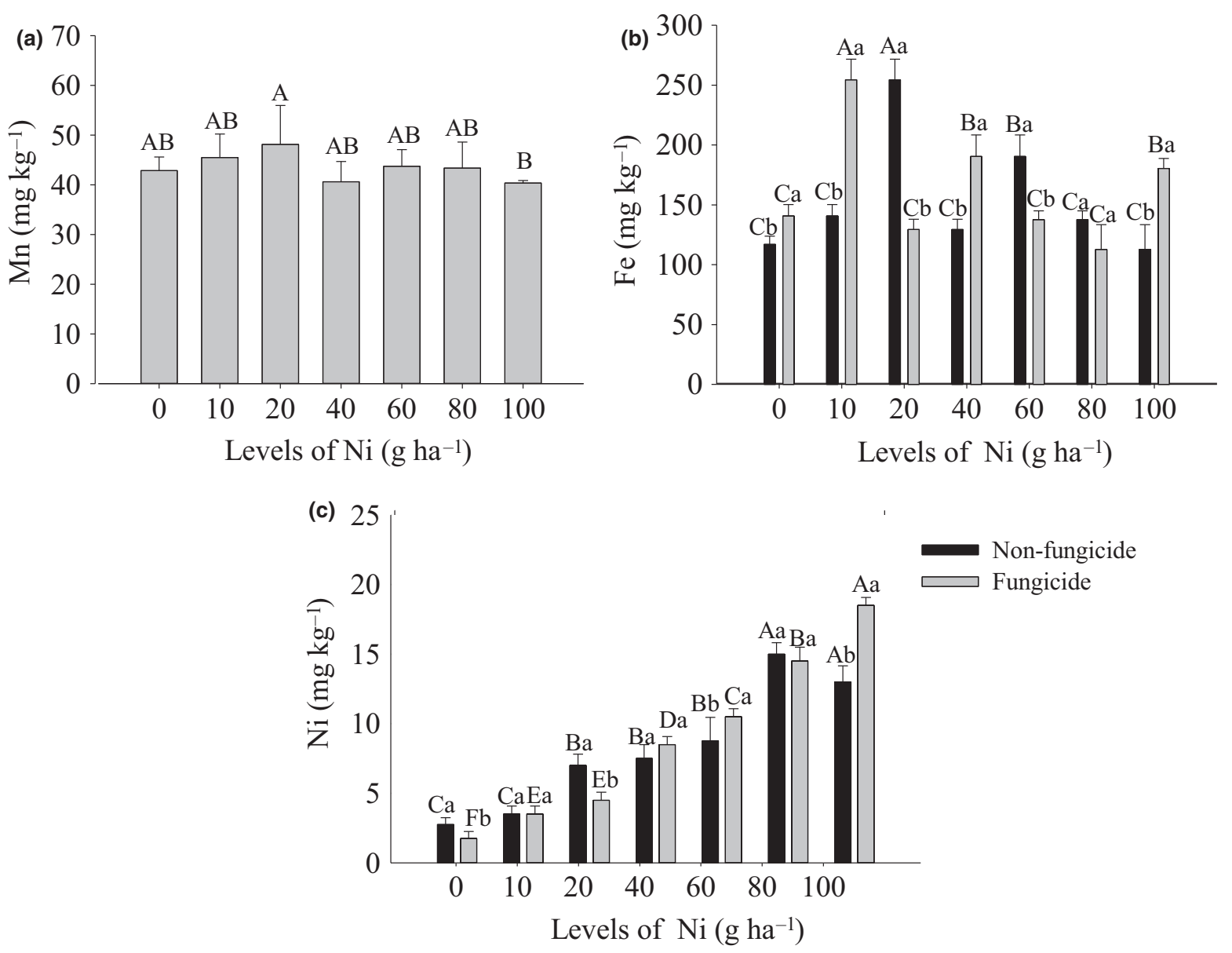

Figure 7 Nutrient concentration in soybean seeds in response to Ni application alone (black bars) or combined with fungicide (fluxapyroxad + pyraclostrobin; grey bars). (a) Manganese, (b) iron, (c) nickel. Means followed by the same lowercase letter comparing the fungicide application and by the same uppercase letter comparing the Ni doses do not differ significantly $(P \leq 0.05)$ according to the Tukey test. The error bars represent the standard error of the mean $(n=4)$.

peroxidation up to the dose of $60 \mathrm{~g} \mathrm{ha}^{-1}$. The application of higher doses significantly increased the lipid peroxidation rate in the soybean leaves.

The application of $\mathrm{Ni}$ doses above $60 \mathrm{~g} \mathrm{ha}^{-1}$, alone or combined with fungicide, promoted a decrease in the SOD, CAT and POD activity and in the $\mathrm{H}_{2} \mathrm{O}_{2}$ concentration (Fig. 9). A significant increase in the lipid peroxidation rate was observed in response to doses above $60 \mathrm{~g} \mathrm{ha}^{-1}$ (Fig. 9f), indicating that the cells underwent oxidative damage.

\section{Discussion}

The number of pods showed a positive correlation with the $\mathrm{Ni}$ concentration in leaves and seeds, but the effect of the treatments was variable. Rodak (2014) applied different $\mathrm{Ni}$ doses to soybean under greenhouse conditions and did not observe a significant $\mathrm{Ni}$ effect on the number of pods. The yield showed a positive correlation with the $\mathrm{Ni}$ concentration in the leaves (Fig. 10), although no significant effect of $\mathrm{Ni}$ doses was observed, as had been reported in several studies on the application of $\mathrm{Ni}$ in soybean (Kutman et al., 2014; Rodak, 2014).

Powdery mildew control in soybean can be achieved by the use of fungicides. Among the fungicides used are the quinone outside inhibitors (QoI) and succinate dehydrogenase inhibitors (SDHI), which act on fungal mitochondrial respiration. QoIs inhibit the electron transport in the mitochondrial complex 3, thus inhibiting fungal respiration and, consequently, ATP formation. The SDHIs act on complex 2 of the electron transport chain, called the succinate dehydrogenase complex, resulting in the blockade of ATP production and the formation of intermediary molecules that are harmful to the cell (Yorinori et al., 2004; Attanayake et al., 2010).

Nickel is a constituent of urease, which is the enzyme responsible for the breakdown of urea into ammonia and carbon dioxide (Dixon et al., 1975) and therefore responsible for the recycling of nitrogen in the plant (Polacco et al., 2013; Fabiano et al., 2015). Nickel, as well as urease, showed no consistent trend in the effect 
of $\mathrm{Ni}$ on nitrogen concentrations in leaves and seeds (Fig. 10). This result corroborates some studies conducted with soybean (Rodak, 2014) in which no changes were observed in the nitrogen concentration in the leaf tissue with the application of $\mathrm{Ni}$.

Regarding the interaction with the other nutrients, in general, the absorption of cationic macro- and micronutrients is reduced at high $\mathrm{Ni}$ concentrations in plant organs. This reduced absorption occurs because Ni uses nonspecific cation transporters, such as YSL (yellow stripe 1-like protein), ZIP (ZRT/IRT-like protein), NRAMP (natural resistance-associated macrophage protein), and nicotianamine synthase. Thus, it causes competition between the divalent cations, including $\mathrm{Cu}^{2+}, \mathrm{Fe}^{2+}$, $\mathrm{Mn}^{2+}$ and $\mathrm{Zn}^{2+}$ (Mizuno et al., 2005).

A reduction in iron uptake by Ni-fertilized plants has been reported (Nishida et al., 2015), and therefore, excess $\mathrm{Ni}$ causes leaf chlorosis symptoms similar to iron deficiency symptoms in plants. Seeking to elucidate the underlying mechanism of Ni phytotoxicity, Nishida et al. (2015) demonstrated that $\mathrm{Ni}$ can use the iron transporter IRT1 (iron-regulated transporter 1), which is homologous to the transporters of the ZIP family, and also stimulates its expression, further accelerating $\mathrm{Ni}$ accumulation in leaf tissue.

Moreover, according to Kazemi et al. (2010), some antioxidant enzymes, such as CAT and POD, contain iron in their structure, which explains the positive correlation between the leaf concentration of iron and CAT and POD activity. Given that high $\mathrm{Ni}$ doses decrease the iron concentration in plant tissue, the reduction of the activity of these enzymes may be due to the lack of iron for their biosynthesis (Kazemi et al., 2010). This may be related to the negative correlation between the leaf $\mathrm{Ni}$ concentration and the activity of CAT and POD enzymes, as well as to the MDA and $\mathrm{H}_{2} \mathrm{O}_{2}$ concentration (Fig. 10).

The leaf $\mathrm{Ni}$ concentration ranged from 3.8 to $38.0 \mathrm{mg} \mathrm{kg}^{-1}$, increasing as a function of its foliar application and independently of the fungicide application. When $\mathrm{Ni}$ was applied with the fungicide, higher $\mathrm{Ni}$ concentration was observed starting at the dose $40 \mathrm{~g} \mathrm{ha}^{-1}$. The $\mathrm{Ni}$ concentration in seeds ranged from 3 to $18 \mathrm{mg} \mathrm{kg}^{-1}$. A pattern similar to the leaf Ni concentration was observed, thus indicating a high translocation rate.

Nickel is a component of the urease prosthetic group (Dixon et al., 1975), and its supply increases the enzyme activity. The increase in urease activity has also been observed in other crops, such as cereals (Brown et al., 1987) and pecan (Carya illinoinensis; Bai et al., 2006). However, at high Ni doses, the urease activity decreases. In the present study, foliar $\mathrm{Ni}$ applications above $60 \mathrm{~g} \mathrm{ha}^{-1}$ alone or combined with fungicide decreased the urease activity in the leaves. Rodak (2014) also obtained a peak of urease activity $\left(0.5\right.$ and $0.6 \mathrm{mg} \mathrm{dm}^{-3}$ of $\mathrm{Ni}$ ), followed by a decrease in enzymatic activity at the higher doses and observed symptoms of $\mathrm{Ni}$ toxicity in the leaves.
Under conditions of low $\mathrm{Ni}$ concentration in the leaf tissue, urea accumulates in the tissues (Eskew et al., 1983). Similar effects were also observed in tomato (Eskew et al., 1983) and cowpea (Vigna unguiculata; Walker et al., 1985). The addition of $\mathrm{Ni}$ to the nutrient solution was shown to relieve the symptoms of toxicity caused by urea accumulation (Tan et al., 2000). The same occurs with foliar $\mathrm{Ni}$ application (Kutman et al., 2014).

In this study, the fungicide used in the absence of $\mathrm{Ni}$ did not reduce the urea concentration. Conversely, application of $\mathrm{Ni}$ in combination with the fungicide treatments resulted in greater urease activity. The urea concentration was higher than that observed for the treatments without fungicide. At the dose of $100 \mathrm{~g} \mathrm{ha}^{-1}$ of $\mathrm{Ni}$ combined with the fungicide, the urea concentration was higher than the concentration observed in the control treatment without $\mathrm{Ni}$, showing that the fungicide effect when combined with $\mathrm{Ni}$ doses, despite contributing to the increase in urease activity, did not contribute to a reduction in the urea concentration.

$\mathrm{Ni}$ indirectly affects plant pathogens via the action of urease. This enzyme in plants has an antifungal

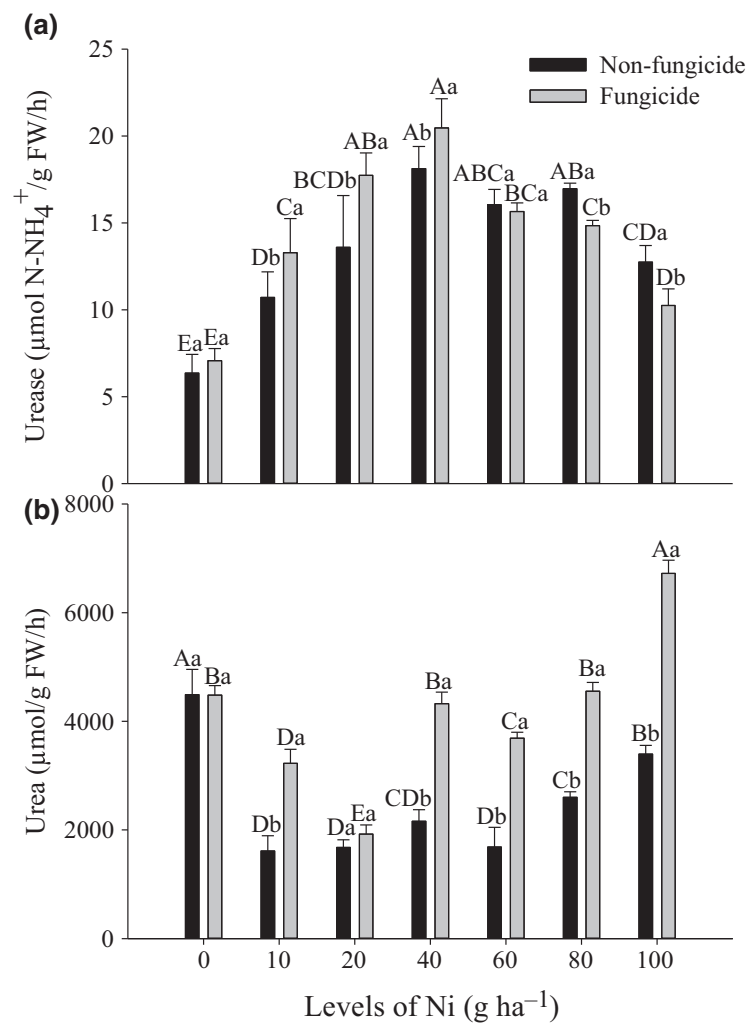

Figure 8 Urease activity (a) and urea concentration (b) in soybean leaf tissue in response to $\mathrm{Ni}$ application alone (black bars) or combined with fungicide (fluxapyroxad + pyraclostrobin; grey bars). Means followed by the same lowercase letter comparing fungicide application and by the same uppercase letter comparing Ni doses do not differ significantly $(P \leq 0.05)$ according to the Tukey test. Error bars indicate the standard deviation of the mean of four replicates $(n=4)$. 
(a)
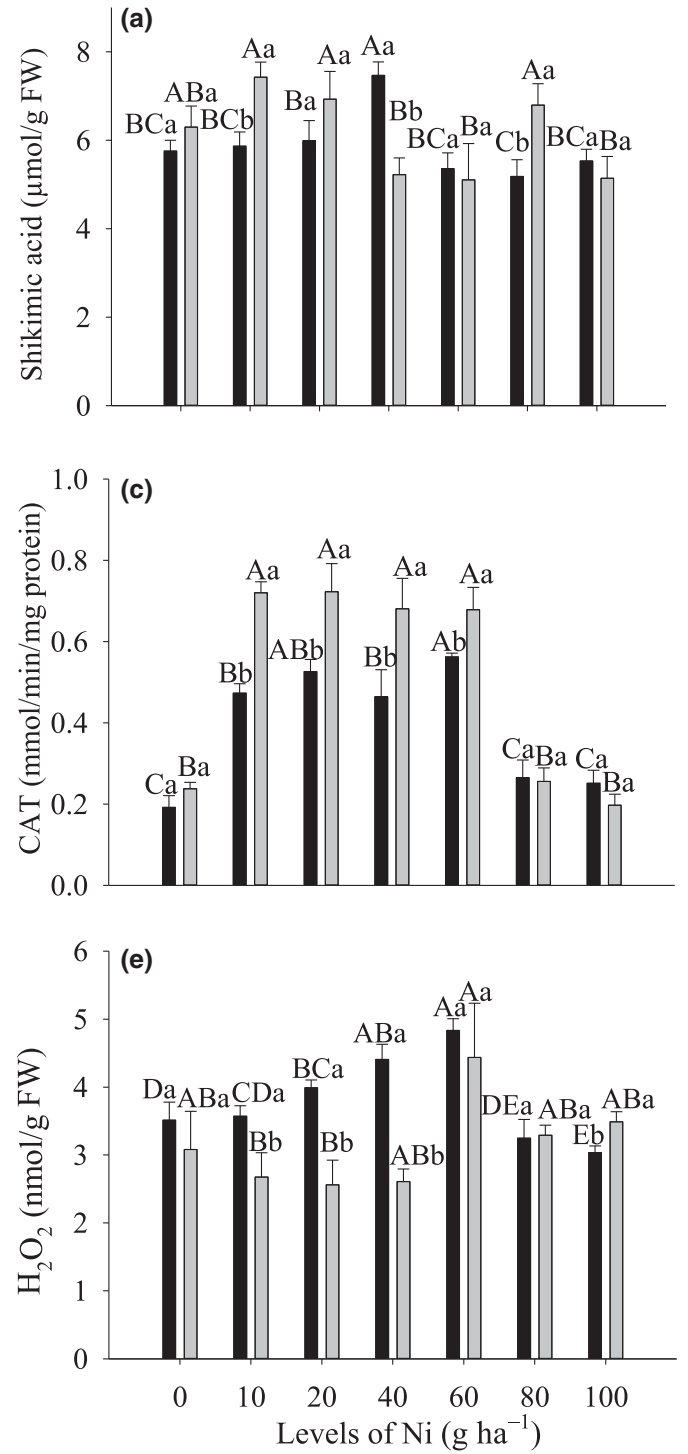
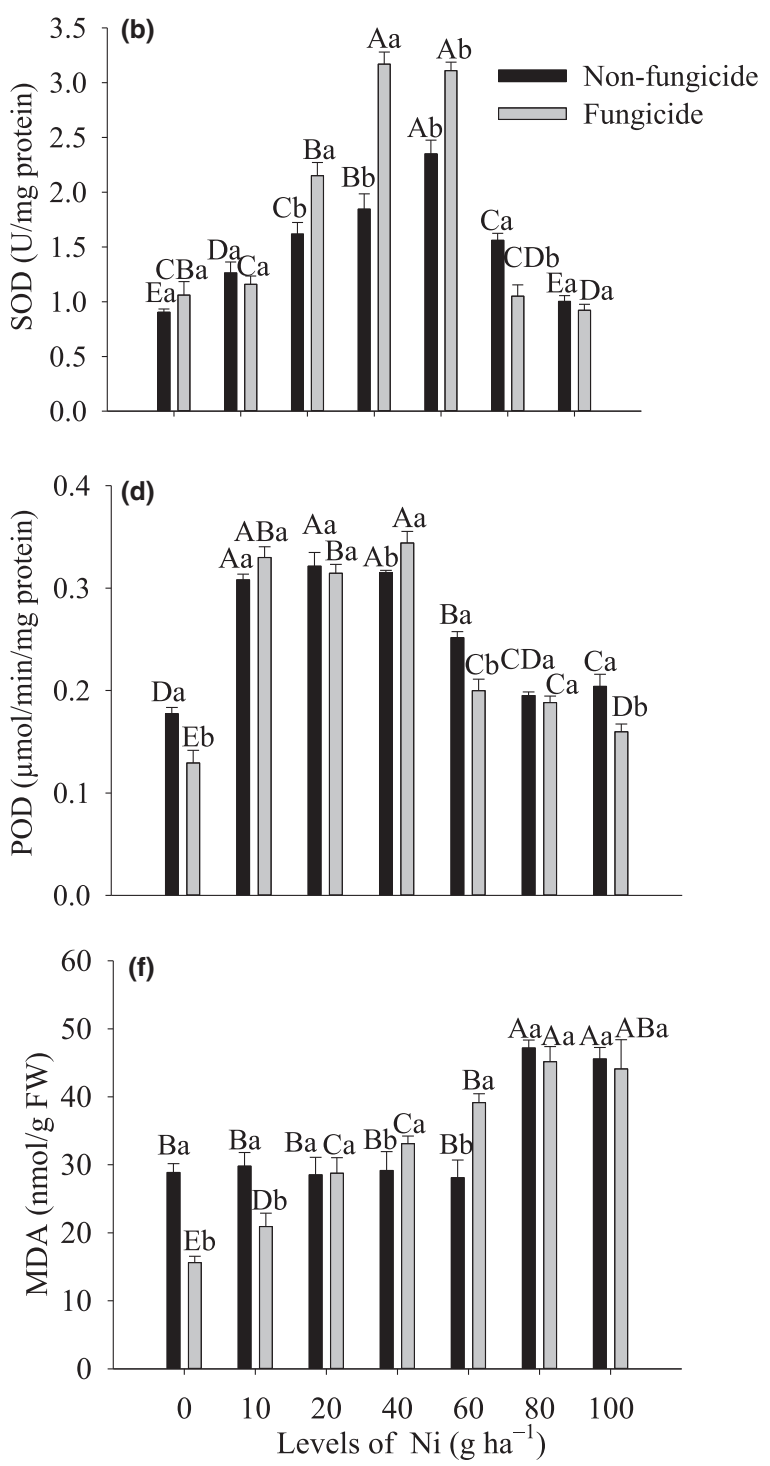

Figure 9 Shikimic acid concentration and antioxidant enzyme activity in soybean leaf tissue as a function of Ni application alone (black bars) or combined with fungicide (fluxapyroxad + pyraclostrobin; grey bars). (a) Shikimic acid concentration, (b) superoxide dismutase activity, (c) catalase activity, (d) peroxidase activity, (e) hydrogen peroxide concentration, (f) lipid peroxidation (measured as MDA concentration). Means followed by the same lowercase letter comparing fungicide application and by the same uppercase letter comparing Ni doses do not differ significantly $(P \leq 0.05)$ according to the Tukey test. Error bars indicate the standard deviation of the mean of four replicates $(n=4)$.

effect (Carlini \& Ligabue-Braun, 2016). Wiebke-Strohm et al. (2012) studied transgenic soybean with suppression of the urease gene and observed that Rhizoctonia solani, Phomopsis sp. and Penicillium herguei presented higher incidence when the urease activity was low under greenhouse conditions. They also observed more evident Phakopsora pachyrhizi foliar lesions in the genotype with the suppressed urease gene. These results corroborate the negative correlation observed in this study between the urease activity and powdery mildew severity.

During the photosynthetic metabolism of plants, ROS are commonly produced, and production is increased under conditions of stress, as in the case of attack by pathogens. Thus, the activation of enzymatic and nonenzymatic antioxidant mechanisms is important for the maintenance of the physiological state of the plant (Thakur \& Sohal, 2013).

Some of the nonenzymatic metabolites produced by plants, such as flavonoids, anthocyanins and phenols, originate in the shikimic acid pathway. These compounds are important in plant defence metabolism, including nonenzymatic defence against oxidative stress (Carlini \& Ligabue-Braun, 2016). Such a defence was observed in this study in the correlation between the shikimic acid and lipid peroxidation. 


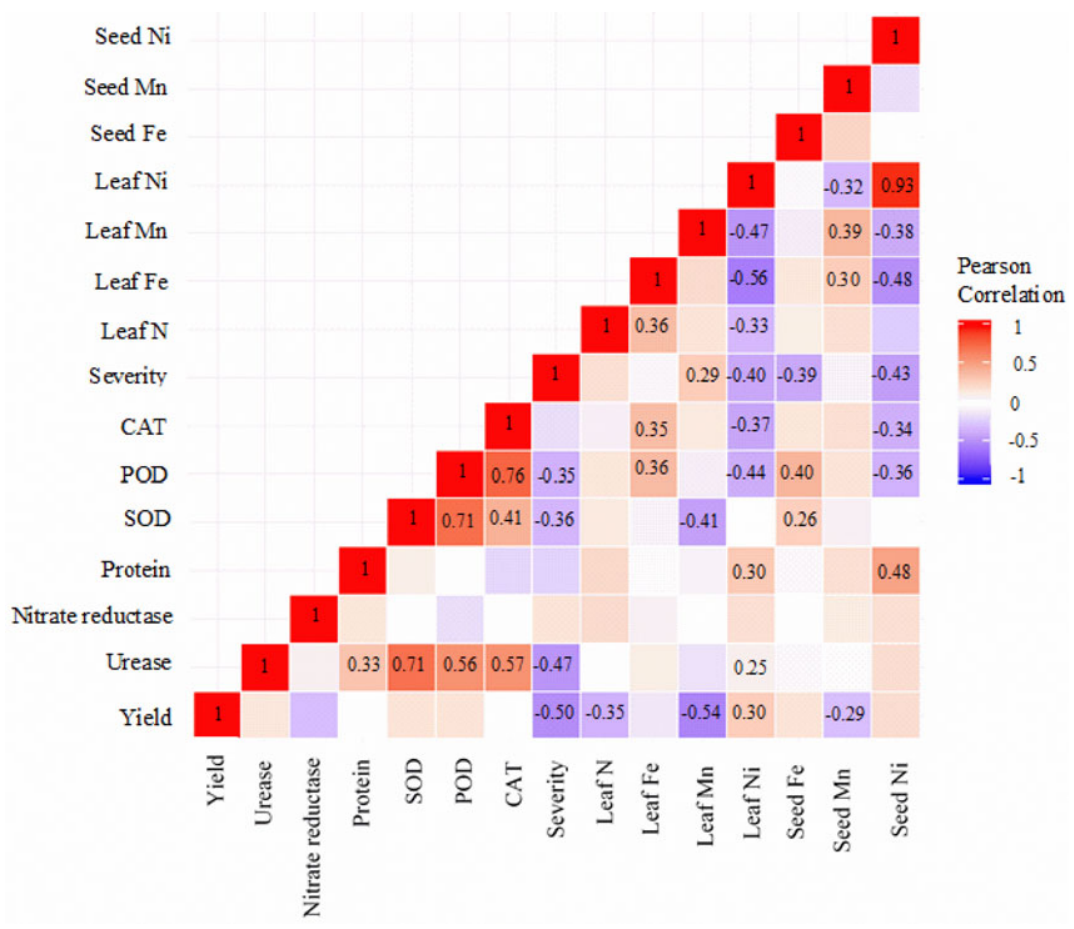

Figure 10 Pearson correlation of analysed parameters in response to $\mathrm{Ni}$ and fungicide application. [Colour figure can be viewed at wileyonlinelibrary.com]

The responses of antioxidant enzymes due to $\mathrm{Ni}$ fertilization may vary among species. Low Ni doses $(<0.2 \mathrm{~mm})$ promote increases in the SOD, CAT and POD activity in soybean $(<2 \mathrm{~mm})$, and therefore $\mathrm{Ni}$ is considered to stimulate antioxidant metabolism, helping to regulate biotic and abiotic stress responses, and contributing to plant defence (Thakur \& Sohal, 2013; Santos et al., 2017).

The Ni doses used did not cause ultrastructural changes in the soybean leaves, and when combined with fungicide, $\mathrm{Ni}$ drastically reduced the powdery mildew severity in the soybean leaves. The maximum recommended dose of $\mathrm{Ni}$ is $40 \mathrm{~g} \mathrm{ha}^{-1}$ combined with $300 \mathrm{~mL} \mathrm{ha}^{-1}$ fungicide to reduce powdery mildew severity and to promote maximal urease, SOD, CAT and POD enzymatic activity.

With increased urease activity, the urea concentration in the leaf decreased, contributing to nitrogen metabolism in the soybean plants. Urease is regulated by $\mathrm{Ni}$ and has an important physiological role in reducing the powdery mildew severity in soybean. In the presence of the fungicide, an increase in yield was observed, but the Ni dose applied had no effect on the soybean yield.

This study clearly shows the effectiveness of $\mathrm{Ni}$ as a plant protectant. In addition, the distinctive contribution of these findings is that urease is a key enzyme regulated by $\mathrm{Ni}$ and is responsible for control of powdery mildew, either with or without fungicide treatment, in soybean plants.

\section{Acknowledgements}

This work was financially supported by a grant from the National Council for Scientific and Technological Development (grant 448783/2014-2). The authors would like to thank the CAPES Foundation for studentship (J.P.Q.B.) granted. A.R.R. also thanks Conselho Nacional de Desenvolvimento Científico e Tecnológico (CNPq) for the research fellowship (grant 309380/2017-0). The authors have no conflicts of interest to declare.

\section{References}

Alexieva V, Sergiev I, Mapelli S, Karanov E, 2001. The effect of drought and ultraviolet radiation on growth and stress markers in pea and wheat. Plant, Cell \& Environment 24, 1337-44.

Attanayake RN, Glawe DA, McPhee KE, Dugan FM, Chen W, 2010. Erysiphe trifolii - a newly recognized powdery mildew pathogen of pea. Plant Pathology 59, 712-20.

Bai C, Reilly CC, Wood BW, 2006. Nickel deficiency disrupts metabolism of ureides, amino acids, and organic acids of young pecan foliage. Plant Physiology 140, 433-43.

Bradford MM, 1976. A rapid and sensitive method for the quantitation of microgram quantities of protein utilizing the principle of proteindye binding. Analytical Biochemistry 72, 248-54.

Brown PH, Welch RM, Cary EE, 1987. Nickel: a micronutrient essential for higher plants. Plant Physiology 85, 801-3.

Carlini CR, Ligabue-Braun R, 2016. Ureases as multifunctional toxic proteins: a review. Toxicon 110, 90-109.

Ciurli S, 2001. Electronic structure of the nickel ions in the active site of urease. Chemistry 2001, 99-100. 
Dixon NE, Gazzola C, Blakeley RL, Zerner B, 1975. Jack bean urease (EC 3.5.1.5). Metalloenzyme. Simple biological role for nickel. Journal of the American Chemical Society 97, 4131-3.

Eskew DL, Welch RM, Cary EE, 1983. Nickel: an essential micronutrient for legumes and possibly all higher plants. Science $\mathbf{2 2 2}$, 621-3.

Fabiano CC, Tezotto T, Favarin JL, Polacco JC, Mazzafera P, 2015. Essentiality of nickel in plants: a role in plant stresses. Frontiers in Plant Science 6, 754.

Giannopolitis CN, Ries SK, 1977. Superoxide dismutases: I. Occurrence in higher plants. Plant Physiology 59, 309-14.

Godoy CV, Seixas CDS, Soares RM, Marcelino-Guimarães FC, Meyer MC, Costamilan LM, 2016. Asian soybean rust in Brazil: past, present, and future. Pesquisa Agropecuaria Brasileira 51, 407-21.

Heath RL, Packer L, 1968. Photoperoxidation in isolated chloroplasts: I. Kinetics and stoichiometry of fatty acid peroxidation. Archives of Biochemistry and Biophysics 125, 189-98.

Hogan ME, Swift IE, Done J, 1983. Urease assay and ammonia release from leaf tissues. Phytochemistry 22, 663-7.

Kazemi N, Khavari-Nejad RA, Fahimi H, Saadatmand S, Nejad-Sattari T, 2010. Effects of exogenous salicylic acid and nitric oxide on lipid peroxidation and antioxidant enzyme activities in leaves of Brassica napus L. under nickel stress. Scientia Horticulturae 126, 402-7.

Kojima S, Bohner A, Gassert B, Yuan L, von Wirén N, 2007. AtDUR3 represents the major transporter for high-affinity urea transport across the plasma membrane of nitrogen-deficient Arabidopsis roots. The Plant Journal 52, 30-40.

Kutman BY, Kutman UB, Cakmak I, 2013. Foliar nickel application alleviates detrimental effects of glyphosate drift on yield and seed quality of wheat. Journal of Agricultural and Food Chemistry 61, 8364-72.

Kutman BY, Kutman UB, Cakmak I, 2014. Effects of seed nickel reserves or externally supplied nickel on the growth, nitrogen metabolites and nitrogen use efficiency of urea- or nitrate-fed soybean. Plant and Soil $376,261-76$.

McCullough H, 1967. The determination of ammonia in whole blood by a direct colorimetric method. Clinica Chimica Acta 17, 297-304.

McTaggart AR, Ryley MJ, Shivas RG, 2012. First report of the powdery mildew Erysiphe diffusa on soybean in Australia. Australasian Plant Disease Notes 7, 127-9.

Mizuno T, Usui K, Horie K, Nosaka S, Mizuno N, Obata H, 2005. Cloning of three ZIP/Nramp transporter genes from a $\mathrm{Ni}$ hyperaccumulator plant Thlaspi japonicum and their $\mathrm{Ni}^{2+}$-transport abilities. Plant Physiology and Biochemistry 43, 793-801.
Nishida S, Kato A, Tsuzuki C, Yoshida J, Mizuno T, 2015. Induction of nickel accumulation in response to zinc deficiency in Arabidopsis thaliana. International Journal of Molecular Sciences 16, 9420-30.

Noctor G, Foyer CH, 2016. Intracellular redox compartmentation and ROS-related communication in regulation and signaling. Plant Physiology 171, 1581-92.

Polacco JC, Mazzafera P, Tezotto T, 2013. Opinion - nickel and urease in plants: still many knowledge gaps. Plant Science 199, 79-90.

Reis AR, Tabei K, Sakakibara Y, 2014. Oxidation mechanism and overall removal rates of endocrine disrupting chemicals by aquatic plants. Journal of Hazardous Materials 265, 79-88.

Reis AR, Favarin JL, Gratão PL, Capaldi FR, Azevedo RA, 2015. Antioxidant metabolism in coffee (Coffea arabica L.) plants in response to nitrogen supply. Theoretical and Experimental Plant Physiology 27, 203-13.

Rodak WR, 2014. Nickel in Soils and Soybean Plants. Curitiba, Brazil: Federal University of Parana, Master's thesis.

Santos EF, Santini JMK, Paixão AP et al., 2017. Physiological highlights of manganese toxicity symptoms in soybean plants: Mn toxicity responses. Plant Physiology and Biochemistry 113, 6-19.

Singh BK, Shaner DL, 1998. Rapid determination of glyphosate injury to plants and identification of glyphosate-resistant plants. Weed Technology 12, 527-30.

Tan XW, Ikeda H, Oda M, 2000. Effects of nickel concentration in the nutrient solution on the nitrogen assimilation and growth of tomato seedlings in hydroponic culture supplied with urea or nitrate as the sole nitrogen source. Scientia Horticulturae 84, 265-73.

Thakur M, Sohal BS, 2013. Role of elicitors in inducing resistance in plants against pathogen infection: a review. ISRN Biochemistry 2013, $1-10$.

Walker CD, Graham RD, Madison JT, Cary EE, Welch RM, 1985. Effects of $\mathrm{Ni}$ deficiency on some nitrogen metabolites in cowpeas (Vigna unguiculata L. Walp). Plant Physiology 79, 474-9.

Wiebke-Strohm B, Pasquali G, Margis-Pinheiro M et al., 2012. Ubiquitous urease affects soybean susceptibility to fungi. Plant Molecular Biology 79, 75-87.

Wood BW, Reilly CC, 2007. Nickel and plant disease. In: Datnnof LE, Elmer WH, Huber DM, eds. Mineral Nutrition and Plant Disease. St Paul, MN, USA: American Phytopathological Society, 215-31.

Yorinori MA, Klingelfuss LH, Paccola-Meirelles LD, Yorinori JT, 2004. Effect of time of spraying of fungicide and foliar nutrient on soybean powdery mildew. Journal of Phytopathology 152, 129-32. 